\title{
Working
}

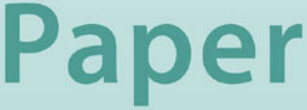




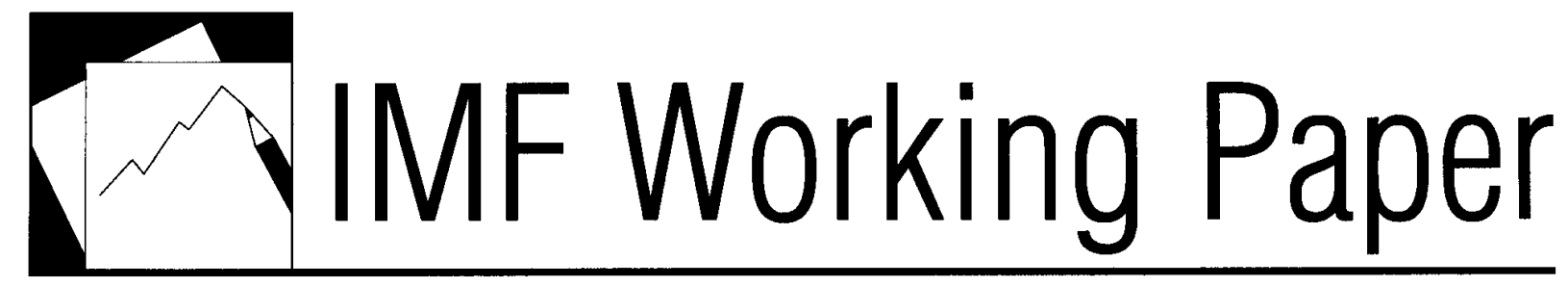

Balance-Sheet Shocks and Recapitalizations

Damiano Sandri and Fabián Valencia 
This page intentionally left blank

(C) International Monetary Fund. Not for Redistribution 


\title{
IMF Working Paper
}

Research Department

\section{Balance-Sheet Shocks and Recapitalizations}

\section{Prepared by Damiano Sandri and Fabián Valencia ${ }^{1}$}

Authorized for distribution by Stijn Claessens

March 2012

\section{This Working Paper should not be reported as representing the views of the IMF.} The views expressed in this Working Paper are those of the author(s) and do not necessarily represent those of the IMF or IMF policy. Working Papers describe research in progress by the author(s) and are published to elicit comments and to further debate.

\begin{abstract}
We develop a dynamic stochastic general equilibrium model with financial frictions on both financial intermediaries and goods-producing firms. In this context, due to high leverage of financial intermediaries, balance sheet disruptions in the financial sector are particularly detrimental for aggregate output. We show that the welfare gains from recapitalizing the financial sector in response to large but rare net worth losses are as large as those from eliminating business cycle fluctuations. We also find that these gains are increasing in the size of the net worth loss, are larger when recapitalization funds are raised from the household rather than the real sector, and may increase with a reduction in financial intermediaries idiosyncratic risk.
\end{abstract}

\section{JEL Classification Numbers:C61, E21, G13}

Keywords: Financial accelerator, bank bailouts, leverage, balance-sheet shocks

Author's E-Mail Address:dsandri@imf.org and fvalencia@imf.org

\footnotetext{
${ }^{1}$ The authors thank Christopher Carroll, Stijn Claessens, Giovanni Dell'Ariccia, Gregory de Walque, Robert Kollmann, Luc Laeven, José Luis Peydro, Jose Victor Rios-Rull, Thierry Tressel, Kenneth West, and seminar participants at the NBER Summer Institute, the IMF, the CEPR-EBC-HEC-NYSE/Euronext-RoF Conference on "Financial Intermediation and the Real Economy", the National Bank of Poland's conference "DSGE and Beyond", and CEPR-National Bank of Belgium-JMCB-ECARES-Ghent University conference on "Macroeconomics and Financial Intermediation" for comments and discussions.
} 
Contents

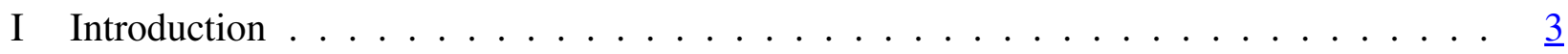

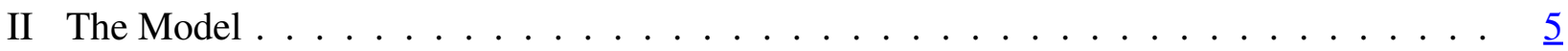

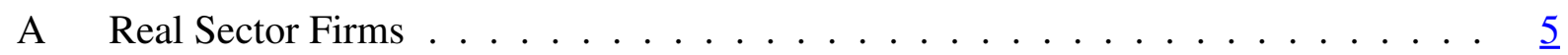

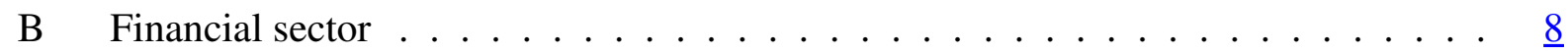

C Equilibrium in the financial and real sectors $\ldots \ldots \ldots \ldots \ldots$

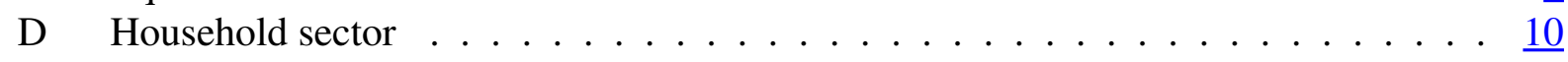

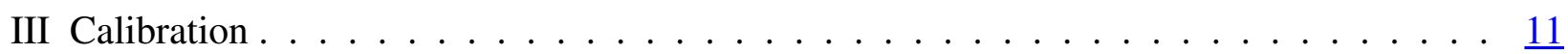

IV Responses to net worth shocks . . . . . . . . . . . . . . . . 13

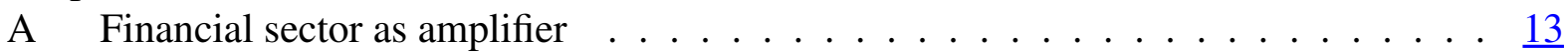

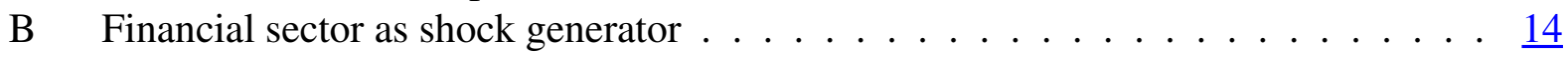

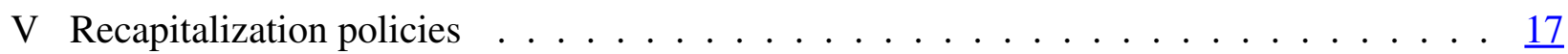

VI Uncertainty shocks . . . . . . . . . . . . . . . . . . . . 19

A Recapitalization Policies and Idiosyncratic Risk . . . . . . . . . . $\underline{20}$

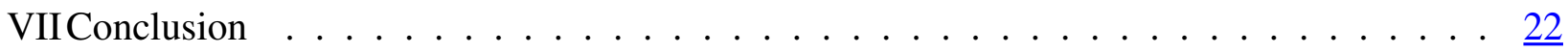

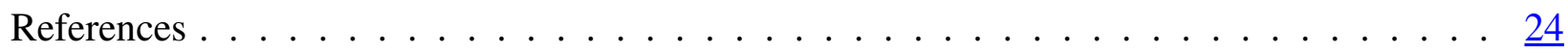

List of Tables

1 Steady State Values and Targets . . . . . . . . . . . . . . . . . 12

List of Figures

1 Sequence of Events . . . . . . . . . . . . . . . . . . . . . 11

2 Financial Variables . . . . . . . . . . . . . . . . . . . 13

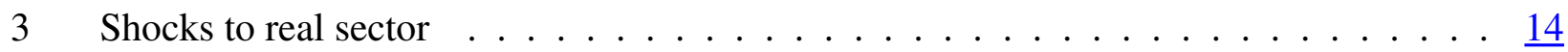

4 Impulse response functions from net worth shocks . . . . . . . . . . . . . . 16

5 Welfare gains from recapitalization and sources . . . . . . . . . . . . . 18

6 Welfare gains from recapitalization and size of the net worth shock . . . . . . . . 19

7 Impulse response functions from net worth shocks and idiosyncratic risk . . . . . . . $\underline{21}$

8 Welfare gains from recapitalization and idiosyncratic risk . . . . . . . . $\underline{22}$ 


\section{INTRODUCTION}

The recent crisis has been characterized by a large collapse in asset values and a severe deterioration of financial intermediaries' balance sheets. This has been associated with the freezing of credit markets and a dramatic contraction in output, which have put pressure on governments and central banks to forcefully step in the economy. Usual monetary and fiscal expansionary policies have been complemented with more unconventional interventions, including the public recapitalization of banks. Inspired by these events, we develop a dynamic stochastic general equilibrium model to quantitatively assess the impact of rare but large shocks to the net worth of financial intermediaries and explore the merit of recapitalization policies.

The model is composed of three sectors, representing households, financial intermediaries, and firms in the non-financial corporate sector that we will refer to as the real sector. The household sector is made of a continuum of risk-averse workers which offer their labor endowment to real firms and deposit their savings with financial intermediaries. The financial sector includes a continuum of financial intermediaries subject to idiosyncratic shocks that raise deposit from households and lend to real firms. Finally, firms in the real sector borrow from financial intermediaries, hire workers and earn a rate of return subject to idiosyncratic shocks. All three sectors face the risk of exogenous net worth losses and both financial and real firms pay dividends to households at an exogenous rate.

The key feature of the model is presence of financial frictions not only on real firms, as already analyzed in the literature, but also on financial intermediaries. In the absence of financial frictions, the distribution of net worth across sectors is inconsequential for aggregate dynamics since capital freely flows to its most productive use through borrowing and lending. Financial frictions - that we model with a costly state verification problem à la Townsend (1979) - prevent this efficient market-based reallocation of capital by generating spreads between the lending and borrowing rates. This implies that a given net worth loss in the economy has different economic implications depending on which sector it impacts.

Calibrating the model to U.S. data, we analyze the responses to a negative shock to the net worth of each of the three sectors. The model generates rich implications for the dynamics of both financial (leverage, spreads, and credit flows) and real variables (GDP, wages and profitability). By considering financial frictions on financial intermediaries, our model reveals the particularly disruptive consequences of a shock to the financial sector. A given net worth loss involves indeed a much larger GDP contraction if it falls on the balance sheets of financial intermediaries rather than on households or real firms. This is essentially due to the high leverage of financial intermediaries that severely impairs their ability to withstand large shocks.

The fact that output losses depend on which sector is directly affected by the net worth shock provides the rationale for recapitalization policies that aim to shift losses to the sectors that can better absorb them. These transfers can in principle be implemented in many different ways, for example by easing monetary policies to reduce borrowing costs, by altering fiscal policies, by purchasing assets to support their values, or more directly through equity injections financed with tax-payer money. In this paper, we do not narrowly focus on any particular form of implementation, but consider more generally the welfare gains from exogenously redistributing 
wealth in response to shocks. Comparing the merit of different implementation procedures becomes an interesting topic of research only after establishing that the potential gains from recapitalization are reasonably large.

We assess the benefits of recapitalization policies in response to infrequent but large shocks that when affecting the financial sector trigger a GDP contraction similar to the US 2008 recession. We find that the gains from recapitalizing the financial sector with funds from the household sector are equivalent to a permanent increase in consumption by $0.15 \%$. To put this number in context, these are the gains that a standard RBC model without financial friction would predict from the elimination of business cycle fluctuations. Therefore, designing and implementing recapitalization policies in case of rare but large shocks to the financial sector could be equally important as the design of countercyclical policies aiming at smoothing business cycle fluctuations.

By including financial frictions on both the financial and the real sector, the model also allows us to consider the merit of recapitalizing the financial sector with funds from the real sector. At a first glance, this may seem inappropriate since the ultimate purpose of policy intervention is to support the level of investment in the real sector. However, since financial intermediaries are more leveraged than real firms, we find that financing the recapitalization with resources from the real sector is still welfare enhancing.

We also use the model to study how the welfare gains from recapitalization policies vary with the level of idiosyncratic risk. ${ }^{2}$. This is an interesting issue in the context of the paper since under costly state verification the level of idiosyncratic volatility controls the importance of financial frictions which provide the rationale for recapitalizations. The model would indeed boil down to a standard frictionless world if idiosyncratic volatility were set to zero. A reduction in volatility can be beneficial for the economy since it reduces financial frictions. However, the model reveals that lower uncertainty also leads to a gradual increase in the leverage of financial intermediaries, which can make the economy less resilient to financial sector shocks and increase the larger welfare gains from recapitalization policies.

The modeling of financial frictions adopted in the paper is borrowed from Carlstrom and Fuerst (1997) and Bernanke, Gertler and Gilchrist (1999) who incorporated Townsend (1979) 's costly state verification framework in a dynamic macro model. The purpose of this early literature on financial frictions, also including Kiyotaki and Moore (1997), was to study the role of agency problems on good-producing firms in amplifying the responses to productivity shocks. Differently from our work, these papers did not feature a financial sector. The recent crisis demonstrated that a credit tightening may not only result from a deterioration in the balance sheets of ultimate borrowers, but also from problems affecting the financial sector itself. Recent papers have thus incorporated a role for the lender either implicitly by shocking the tightness of credit constraints (Gilchrist et al. (2010), Quadrini and Jermann (2011), and Cúrdia and Woodford (2009)), or by imposing financial frictions only on financial intermediaries (Gertler and Kiyotaki (2009)).

\footnotetext{
${ }^{2}$ Recent papers that give a prominent role to uncertainty shocks include Arellano, Bai and Kehoe (2011), Bloom, Floetotto and Jaimovich (2011), Christiano, Motto and Rostagno (2009), and Gilchrist, Sim and Zakrajšek (2010)
} 
The main innovation in our paper is to consider financial frictions on both financial intermediaries and good-producing firms. Apart from improving the realism of the model, our setup allows us to compare the responses to shocks in the financial and real sector and assess the impact of wealth transfers between these two sectors. A double layer of financial frictions was first introduced by Holmstrom and Tirole (1997) but in a static setting and with an exogenous lending rate by households. The models by Chen (2001) and Meh and Moran (2010) also feature financial frictions on both banks and firms, but using an agency problem based on limited enforcement rather than on costly state verification. The advantage of the latter approach adopted in our paper is that it allows for the analysis of time-varying borrowing spreads and for the possibility of recapitalizing the financial sector with funds from the real sector which has instead no impact on output in the just cited papers. Hirakata, Sudo and Ueda (2011) also present a model with a costly state verification problem on both banks and real firms. Our work differs from theirs in two important ways: First, they assume a monopolistic bank, while we consider a competitive banking sector. Second, they solve the model with standard log-linear approximation methods, while we use global methods because the size of shocks associated with a systemic banking crisis are large enough that the system moves significantly away from the steady state. Finally, our paper shares with Gertler and Karadi (2010) and Del Negro, Eggertsson, Kiyotaki and Ferrero (2011) the purpose of analyzing unconventional policies in response to financial crises, but our focus in on recapitalizations instead of credit policies and liquidity support. Kollmann, Roeger and in't Veld (2012) also study the merit of bank aid policies considering the impact on GDP, while we examine the implications for welfare.

This paper is organized as follows. The next section introduces the model which we calibrate in Section III. Section IV presents quantitative experiments showing the model responses to net worth shocks. We introduce recapitalization policies and analyze their welfare effects in Section $\mathrm{V}$, and assess how these gains are affected by idiosyncratic risk in Section VI. Section VII concludes.

\section{THE MODEL}

We consider a closed economy composed by the household, financial and real sectors. Households work for firms in the real sector and deposit their savings with financial intermediaries. The financial sector intermediates households' savings by extending loans to firms producing goods in the real sector. The key element of the model is that both financial intermediaries and goods-producing firms are subject to financial frictions. We now proceed to formally describe the optimization problems faced by households and firms in the financial and real sector.

\section{A. Real Sector Firms}

The real sector ( $r$ superscript) is composed of a continuum of competitive firms with mass one. Each firm is managed by a risk-neutral entrepreneur that maximizes expected profits. Real sector entrepreneurs invest in productive capital $k_{t}$ using their own net worth $e_{t}^{r}$ and taking out loans $l_{t}^{r}$ 
from financial entrepreneurs. They have access to a Cobb-Douglas production function combining capital and labor and returning revenues net of depreciation $\delta$ equal to

$$
\left((1-\delta) k_{t}+k_{t}^{\alpha} n_{t}^{1-\alpha}-n_{t} W_{t}\right) \omega_{t+1}^{r}
$$

where $\omega_{t+1}^{r}$ is a mean one idiosyncratic shock with cumulative distributive function $\Omega^{r}, W_{t}$ is the competitive market wage, and $n_{t}$ is the amount of labor hired from the household sector. ${ }^{3}$ The optimal demand for labor is given by

$$
n_{t}^{*}=k_{t}\left(\frac{1-\alpha}{W_{t}}\right)^{1 / \alpha}
$$

which, if substituted out, allows us to rewrite expected net revenues in equation (1) as

$$
k_{k_{t}} \overbrace{\left(\neg+\alpha\left(\frac{1-\alpha}{W_{t}}\right)^{(1-\alpha) / \alpha}\right)}^{A_{t}} \omega_{t+1}^{r}
$$

where $A_{t}$ is the expected return to capital common to all entrepreneurs because it does not depend on any firm specific variable.

As in Carlstrom and Fuerst (1997) and Bernanke et al. (1999), we introduce financial frictions through an agency problem caused by costly state verification à la Townsend (1979). In particular, external investors can observe the realization of the idiosyncratic shock $\omega_{t+1}^{r}$ only after paying a monitoring cost equal to a fraction $\mu^{r}$ of their loan. As shown by Gale and Hellwig (1985) and Williamson (1987), the optimal contract in this setting involves risky debt, so financial entrepreneurs will monitor real sector entrepreneurs only if they declare to be insolvent. This happens any time liabilities exceed assets:

$$
l_{t}^{r}\left(1+r_{t}^{r}\right) \geq k_{t} A_{t} \omega_{t+1}^{r}
$$

or in other words any time the idiosyncratic shock $\omega_{t+1}^{r}$ is lower than

$$
\underline{\omega}^{r}=\frac{l_{t}^{r}\left(1+r_{t}^{r}\right)}{k_{t} A_{t}}
$$

where $r_{t}^{r}$ is the firm-specific interest rate. This rate has to ensure an expected return to financial intermediaries equal to the average market return $r_{t}$

$$
\left(1+r_{t}\right)=\left(1-\mu^{r}\right) \int_{0}^{\underline{\omega}^{r}} \frac{k_{t}}{l_{t}^{r}} A_{t} \omega^{r} \mathrm{~d} \Omega^{r}\left(\omega^{r}\right)+\left(1-\Omega^{r}\left(\underline{\omega}^{r}\right)\right)\left(1+r_{t}^{r}\right)
$$

where the first and second terms on the right-hand side capture respectively the return to financial

\footnotetext{
${ }^{3}$ Notice that we assume that idiosyncratic risk affects profits rather than revenues as it would under a traditional productivity shock interpretation. This is done for two reasons: first, it allows us to preserve linearity of the problem, facilitating aggregation as it will be seen momentarily, and second, it means the wage is not affected by the idiosyncratic risk since workers collect it before the shock is realized.
} 
intermediaries if the real sector firm goes bankrupt or is solvent. ${ }^{4}$

The entrepreneur's objective is to maximize the expected profit

$$
e_{t}^{r} \overbrace{\int_{\underline{\omega}^{r}}^{\infty}\left(\frac{k_{t}}{e_{t}^{r}} A_{t} \omega^{r}-\frac{l_{t}^{r}}{e_{t}^{r}}\left(1+r_{t}^{r}\right)\right) \mathrm{d} \Omega^{r}\left(\omega^{r}\right)}^{\Pi_{t}^{r}}
$$

subject to definition (5) and the constraint (6). As shown in Bernanke et al. (1999), this optimization problem boils down to choosing optimal leverage $\lambda_{t}^{r}=k_{t}^{r} / e_{t}^{r}$, which maximizes the expected profit rate $\Pi_{t}^{r}$ given the ratio $A_{t} /\left(1+r_{t}\right){ }^{5}$ Note that expected profits are concave in leverage due to the increasing risk of default and the borrowing cost $r_{t}^{r}$. Quite importantly for the tractability of the general equilibrium solution, optimal leverage is not a function of internal equity $e_{t}^{r}$ because of the assumption of linear investment and monitoring technology. This implies that all firms have equal leverage, so that we have to include in the model's state space only the aggregate equity in the real sector $E_{t}^{r}$, instead of the entire distribution of equity across firms.

After the idiosyncratic shock $\omega_{t+1}^{r}$ is realized, entrepreneurs distribute a share $\mathfrak{D}^{r}$ in dividends to the household. ${ }^{6}$ This dividend distribution assumption is needed to rule out complete self-financing of the real sector which would make financial frictions irrelevant.

Summing up and focusing on the aggregate dynamics of the real sector, entrepreneurs observe at the beginning of the period their net worth $e_{t}^{r}$ and based on the average returns on borrowing $r_{t}$ and investing $A_{t}$ choose the optimal leverage $\lambda_{t}^{r}$. The fact that leverage is common across firms implies that the aggregate borrowing and investment in the real sector (denoted by upper case variables) are simply given by:

$$
\begin{aligned}
L_{t}^{r} & =E_{t}^{r}\left(\lambda_{t}^{r}-1\right) \\
K_{t} & =E_{t}^{r} \lambda_{t}^{r}
\end{aligned}
$$

Dividends for the household are equal to

$$
\chi_{t}^{r}=\mathfrak{D}^{r} E_{t}^{r} \Pi_{t}^{r}
$$

where we use the law of large numbers to write ex-post returns $\Pi_{t}^{r}$ as the average across idiosyncratic risk realizations. Finally, aggregate net worth in the real sector evolves according to

$$
E_{t+1}^{r}=\left(1-\mathfrak{D}^{r}\right) E_{t}^{r} \Pi_{t}^{r}-\Upsilon_{t+1}^{r}
$$

\footnotetext{
${ }^{4}$ The average market return $r_{t}$ will be determined in equilibrium and is the return earned by the financial intermediary on a fully diversified lending portfolio.

${ }^{5}$ This follows simply from the fact that Equation (6) can be expressed in terms of spreads (or ratios) relative to $A_{t}$. Similarly, Equation (7) can also be normalized in the same way, resulting in an equivalent problem in which the key argument is the ratio $A_{t} /\left(1+r_{t}\right)$.

${ }^{6}$ In Bernanke et al. (1999) $\mathfrak{D}^{r}$ is the fraction of entrepreneurs who die in each period who consume their net worth at the moment of death. We instead assume that money flows back to the household so that there is a unique value function in the model that is used to assess the welfare gains from recapitalization.
} 
where $\Upsilon_{t+1}^{r}$ denotes aggregate net worth shocks. These can be interpreted as a reduced-form modeling of asset value shocks that eventually have an impact on net worth. We choose not to model asset shocks more explicitly because their realization would generate immediate losses in other sectors since a larger fraction of firms would go bankrupt on impact. Our modeling choice prevents this immediate spreading of the shocks by assuming that they hit at the end of the period after debts have been repaid. Using net worth shocks is also instrumental to more naturally capture the effects of recapitalization policies which aim to redistribute capital between sectors.

\section{B. Financial sector}

The financial sector ( $f$ superscript) is modeled in the same way as the real sector, with the exception that external financing is raised from households (rather than from financial intermediaries) and that resources are lent to real sector firms (rather than invested in final production). Financial entrepreneurs use their own net worth $e_{t}^{f}$ and the deposits raised from workers $d_{t}^{f}$ to lend funds $l_{t}^{f}=e_{t}^{f}+d_{t}^{f}$ to firms in the real sector. Revenues from lending are given by:

$$
l_{t}^{f}\left(1+r_{t}\right) \omega_{t+1}^{f}
$$

where $\omega_{t+1}^{f}$ is a mean-one idiosyncratic shock with cumulative distributive function $\Omega^{f}$, and $r_{t}$ is the average market return on loans to the real sector after averaging across all loans. We interpret these shocks as some form of managerial ability in collecting loans. Note that $r_{t}$ is a safe return since financial entrepreneurs are assumed to fully diversify their lending and insure against idiosyncratic shocks in the real sector. Furthermore, $r_{t}$ is also independent from aggregate shocks to the net worth of the real sector since they are realized after loans have been repaid.

The same agency problem described for real sector entrepreneurs applies to the entrepreneurs in the financial sector. Financial firms become insolvent if the idiosyncratic shock $\omega_{t+1}^{f}$ is lower than

$$
\underline{\omega}^{f}=\frac{d_{t}^{f}\left(1+i_{t}^{f}\right)}{l_{t}^{f}\left(1+r_{t}\right)}
$$

where $i_{t}^{f}$ is the firm-specific interest rate which needs to ensure an expected return to the lender (i.e. depositors) equal to the risk-free return $i_{t}$ that households gain by fully diversifying their deposits. This participation constraint requires

$$
\left(1+i_{t}\right)=\left(1-\mu^{f}\right) \int_{0}^{\underline{\omega}^{f}} \frac{l_{t}^{f}}{d_{t}^{f}}\left(1+r_{t}\right) \omega^{f} \mathrm{~d} \Omega^{f}\left(\omega^{f}\right)+\left(1-\Omega^{f}\left(\underline{\omega}^{f}\right)\right)\left(1+i_{t}^{f}\right)
$$

where the first and second terms on the right-hand side capture respectively the return to depositors if the financial intermediary goes bankrupt or is solvent. 
The entrepreneur's objective is to choose leverage $\lambda_{t}^{f}=l_{t}^{f} / e_{t}^{f}$ as to maximize the expected profit

$$
e_{t}^{f} \overbrace{\int_{\underline{\omega^{f}}}^{\infty}\left(\frac{l_{t}^{f}}{e_{t}^{f}}\left(1+r_{t}\right) \omega^{f}-\frac{d_{t}^{f}}{e_{t}^{f}}\left(1+i_{t}^{f}\right)\right) \mathrm{d} \Omega^{f}\left(\omega^{f}\right)}^{\Pi_{t}^{f}}
$$

subject to definition (13) and the constraint (14). Optimal leverage is only a function of the ratio $\left(1+r_{t}\right) /\left(1+i_{t}\right)$ and is thus common to all entrepreneurs. Therefore, we only have to keep track of aggregate net worth $E_{t}^{f}$ in the financial sector to solve for the model dynamics. After the realization of the idiosyncratic shock $\omega_{t+1}^{f}$, solvent entrepreneurs repay their debt to depositors and then distribute a share $\mathfrak{D}^{f}$ of their net worth in dividends to the household.

The aggregate dynamics of the financial sector are analogous to those of the real sector. Aggregate borrowing and lending are given by:

$$
\begin{aligned}
D_{t}^{f} & =E_{t}^{f}\left(\lambda_{t}^{f}-1\right) \\
L_{t}^{f} & =E_{t}^{f} \lambda_{t}^{f}
\end{aligned}
$$

After the realization of the idiosyncratic shocks and the repayment of debt contracted with the households, the entrepreneurs distribute dividends to households equal to

$$
\chi_{t}^{f}=\mathfrak{D}^{f} E_{t}^{f} \Pi_{t}^{f}
$$

Finally, next period net worth is given by

$$
E_{t+1}^{f}=\left(1-\mathfrak{D}^{f}\right) E_{t}^{f} \Pi_{t}^{f}-\Upsilon_{t+1}^{f}
$$

where $\Upsilon_{t+1}^{f}$ is an aggregate net worth shock affecting the financial sector.

\section{Equilibrium in the financial and real sectors}

Before closing the model with the household sector, it is useful to describe the equilibrium in credit markets for a given level of the risk-free deposit rate $i_{t}$. In equilibrium, the marginal product of capital, $A_{t}$, is determined by the total amount of capital that is used in production by all entrepreneurs. The assumption of competitive markets and the constant returns to scale production function at the individual level ensures that the aggregate production function is simply $K_{t}^{\alpha} N^{1-\alpha}$, where $N$ denotes the aggregate and fixed labor supply, implying that $\left.A_{t}=(\urcorner+\alpha K_{t}^{\alpha-1}\right)$. Considering that the real sector leverage is exclusively a function of $A_{t} /\left(1+r_{t}\right)$, for a given $r_{t}$ and $E_{t}^{r}$, the equilibrium return on capital, $A_{t}$, is thus given by the solution to $\left.A_{t}=\right\urcorner+\alpha E_{t}^{r}\left(\lambda^{r}\left(A_{t} /\left(1+r_{t}\right)\right)\right)^{\alpha-1}$.

With this solution on hand, the amount of loans demanded by the real sector, $L^{r}$, is a function of the amount of equity in the real sector and the average market return on loans demanded by the financial sector, $L^{r}\left(E_{t}^{r}, r_{t}\right)=E_{t}^{r}\left(\lambda^{r}\left(A\left(E_{t}^{r}, r_{t}\right) /\left(1+r_{t}\right)\right)-1\right)$, where $A\left(E_{t}^{r}, r_{t}\right)$ is the equilibrium return on capital obtained above. Similarly, the financial sector optimal leverage only depends on 
$\left(1+r_{t}\right) /\left(1+i_{t}\right)$, and the supply of loanable funds, $L^{f}$, is a function of $r_{t}, i_{t}$, and $E^{f}$, $L^{f}\left(E_{t}^{f}, r_{t}, i_{t}\right)=\left(\lambda^{f}\left(r_{t} /\left(1+i_{t}\right)\right) E_{t}^{f}\right.$.

For a given risk-free rate, $i_{t}$, and capitalization levels in the financial and real sector, $E_{t}^{f}, E_{t}^{t}$, the equilibrium risk-free lending rate, $r_{t}$, solves $L^{r}\left(E_{t}^{r}, r_{t}\right)=L^{f}\left(E_{t}^{f}, r_{t}, i_{t}\right)$. Note that the state space of the model thus boils down to the triplet $E_{t}^{r}, E_{t}^{f}$, and $i_{t}$.

\section{Household sector}

The household sector ( $h$ superscript) is formalized with a representative household that maximizes the present discounted value of consumption $C_{t}^{h}$ under a CRRA utility function with risk aversion coefficient $\gamma$. The Household supplies labor inelastically to the real sector, deposits savings $D_{t}$ with financial intermediaries, and receives dividends from both real $\chi_{t}^{r}$ and financial $\chi_{t}^{f}$ entrepreneurs. The household's net worth, $E_{t}^{h}$, then evolves according to:

$$
E_{t+1}^{h}=\overbrace{\left(E_{t}^{h}-C_{t}^{h}\right)}^{D_{t}^{h}}\left(1+i_{t}\right)+\chi_{t}^{r}+\chi_{t}^{f}+W_{t}-\Upsilon_{t+1}^{h}
$$

where $D_{t}^{h}$ is the supply of deposits, $W_{t}$ is the market competitive wage, and $\Upsilon_{t+1}^{h}$ is an aggregate shock affecting household wealth. Note that the rate of return earned on deposits $i_{t}$ is riskless since the household diversifies the deposits to insure against the idiosyncratic risk in the financial sector. $^{7}$ This return is also protected from aggregate risk since we assume that aggregate shocks to the net worth of financial intermediaries are realized after deposits have been honored.

The model is closed by solving for the $i_{t}$ that ensures market clearing between supply and demand for deposits. The state space of the model boils down to keeping track only of each sector's aggregate net worth. This allows us to write the household's value function as follows

$$
\begin{aligned}
V^{h}\left(E_{t}^{h}, E_{t}^{r}, E_{t}^{f}\right) & =\max _{\left\{C_{t}\right\}}\left\{u\left(C_{t}^{h}\right)+\beta \mathbb{E}_{t}\left[V^{h}\left(E_{t+1}^{h}, E_{t+1}^{r}, E_{t+1}^{f}\right)\right]\right\} \\
& \text { s.t. } \\
E_{t+1}^{h} & =(\overbrace{\left(E_{t}^{h}-C_{t}^{h}\right.}^{D_{t}^{h}}\left(1+i_{t}\right)+\chi_{t}^{r}+\chi_{t}^{f}+W_{t})-\Upsilon_{t+1}^{h} \\
D_{t}^{h} & =E_{t}^{f}\left(\lambda^{f}-1\right) \\
E_{t+1}^{f} & =\left(1-\mathfrak{D}^{f}\right) E_{t}^{f} \Pi_{t}^{f}-\Upsilon_{t+1}^{f} \\
E_{t+1}^{r} & =\left(1-\mathfrak{D}^{r}\right) E_{t}^{r} \Pi_{t}^{r}-\Upsilon_{t+1}^{r}
\end{aligned}
$$

where $\beta$ is the intertemporal discount factor. Figure 1 summarizes the sequence of events for the whole model. We solve the model with global solution methods building on Carroll (2006)'s method of endogenous gridpoints.

\footnotetext{
${ }^{7}$ This can be thought of as a mutual fund investment.
} 


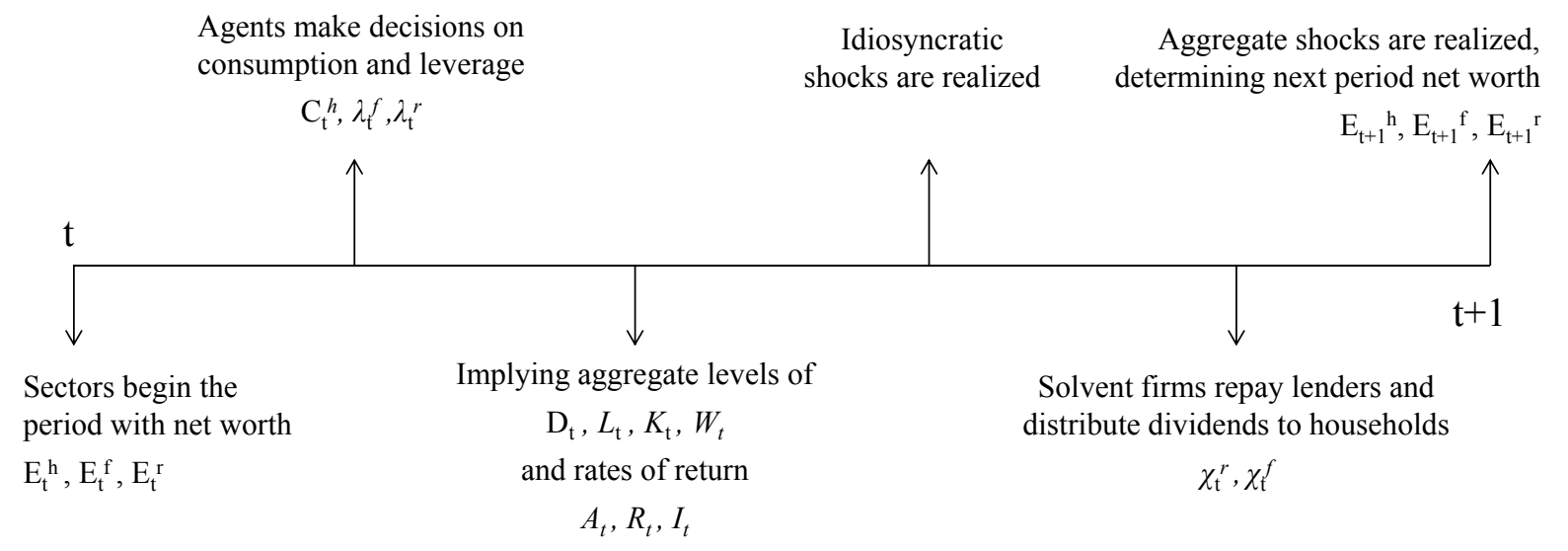

Figure 1. Sequence of Events

\section{Calibration}

We calibrate the model at quarterly frequency setting the depreciation rate, $\delta$ and share of capital, $\alpha$, in the production function to standard levels of $2.5 \%$ and $36 \%$ respectively. The discount factor for the household is set equal to 0.994 , which generates a steady state level for risk-free deposit rate $i_{t}$ of roughly 2 percent in annual terms. We calibrate the remaining parameters to match statistics of leverage, borrowing spreads, and bankruptcies in the real and financial sectors in the deterministic steady state. This is computed as the point in the state space where the model converges to if no net worth shocks hit the economy. This is also the initial point from which all our impulse response functions originate.

Data show that financial and non-financial firms have somewhat different bankruptcy rates and risk spreads, but the greater source of difference is in leverage (Table 1). In our model, we could generate the differences in leverage by using a higher dividend rate in the financial sector, which would exogenously shrink its net worth. However, this would also artificially inflate the rate of return on financial firms and thus possibly the welfare gains from their recapitalization.

Therefore, we constrain ourselves to use the same dividend rate in both the real and financial sectors, which leaves us with five parameters - the dividend rate and the standard deviation of idiosyncratic shocks and size of monitoring costs in each sector - to match six moments, i.e. the financial and real sectors' leverages, spreads, and bankruptcy rates. This implies that to achieve higher leverage in the financial sector we need to reduce the extent of financial frictions on financial intermediaries, both in terms of monitoring costs and idiosyncratic risk. We set the monitoring costs in the financial and real sector to 0.12 and 0.36 respectively. In the context of the model, these are equivalent to bankruptcy costs and are within the range of values considered as empirically plausible (Carlstrom and Fuerst (1997)). We chose a mean-one lognormal distribution for idiosyncratic risk with standard deviations equal to 0.22 for the real sector and 0.06 for financial sector firms. Finally, the exogenous dividend rate is set at $4.7 \%$ in both sectors. The resulting steady state outcomes and data moments are shown in Table 1.

Regarding the calibration of the aggregate shock, we assume that each sector's net worth shock, $\Upsilon^{h}, \Upsilon^{r}, \Upsilon^{f}$ involves the same absolute loss equal to a proportion $\Phi$ of the total net worth in the 
Table 1. Steady State Values and Targets

\begin{tabular}{|c|c|c|}
\hline Variable & Model & Data \\
\hline Leverage Financial Sector & 7.5 & $10.3^{1}$ \\
\hline Leverage Real Sector & 2.4 & $2.0^{2}$ \\
\hline Risk Spread Financial Sector & $40 \mathrm{bps}$ & $44 \mathrm{bps}^{3}$ \\
\hline Risk Spread Real Sector & $127 \mathrm{bps}$ & 110 bps $^{3}$ \\
\hline Bankruptcy Rate Financial Sector & $3.0 \%$ & $2.1 \%^{4}$ \\
\hline Bankruptcy Rate Real Sector & $3.1 \%$ & $3.0 \%^{5}$ \\
\hline
\end{tabular}

economy $E^{h}+E^{f}+E^{r}$. $\Phi$ is set equal to $4 \%$ and is chosen so that when the networth loss affects the financial sector, GDP falls by about $4 \%$ as experienced by the US in 2008Q4. Each of the shock is realized with probability 1 over 75 . This implies that each sector is expected to receive a shock every 75 years, roughly equivalent to the time gap between the Great Depression and the Great Recession.

Figure 2 shows how some key variables depend on the capitalization of the real and financial sectors using the calibrated parameters and setting the deposit rate $i_{t}$ to its deterministic steady state level. Optimal leverage for real sector firms declines as net worth in the sector increases, since more net worth implies higher investment, higher capital, and thus lower returns which reduce the incentives to lever up. Optimal leverage increases in net worth of the financial sector because the larger the supply of credit the lower the borrowing costs. Financial firms' leverage also decreases with net worth in the sector since larger net worth increases the supply of credit and reduces returns. The charts depicting the behavior of risk spreads show that they move in the same direction as leverage, since higher leverage implies higher default risk. Finally, the right-side charts show the evolution of capital and wages in the economy. 

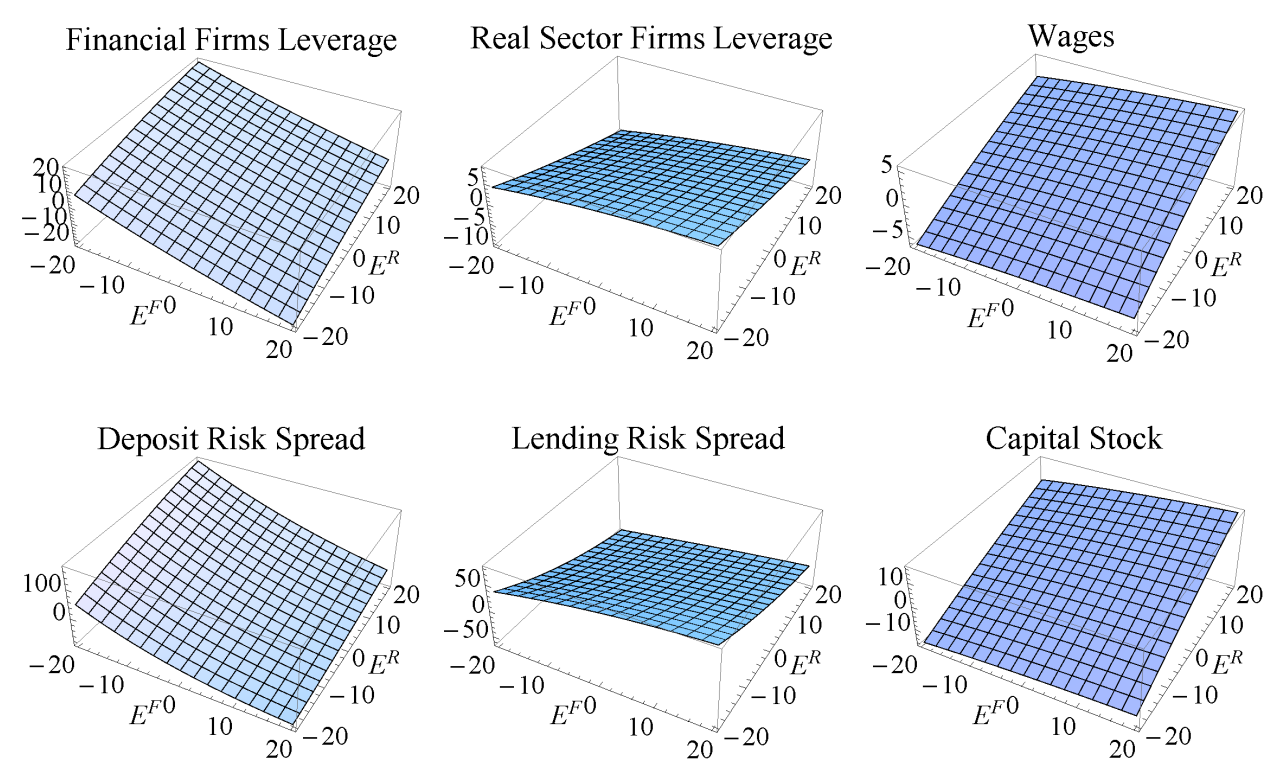

Figure 2. Financial Variables

\section{RESPONSES TO NET WORTH SHOCKS}

In this section we analyze the model responses to shocks that reduce the net worth in the household, financial and real sector. We begin by considering in section A the role of the financial sector in amplifying shocks originating in the real sector. We find no amplification effects when shocks originate in the real sector, since the intermediation margin remains fairly stable. But the financial sector can become itself a strong generator of shocks. In section B we show indeed that the economic disruption caused by a given aggregate destruction of net worth is much more severe if the losses are concentrated on the balance sheets of the financial sector.

\section{A. Financial sector as amplifier}

We examine how the addition of frictions on financial intermediaries changes the dynamic adjustment in the economy relative to a benchmark in which financial frictions are present only on real sector firms. This benchmark is comparable to Bernanke et al. (1999) and Carlstrom and Fuerst (1997) in which the capitalization of the financial sector does not matter because financial intermediaries face no financial frictions. In conducting this experiment, we shut down the possibility of aggregate shocks to the household and financial entrepreneur's net worth and solve the problem under the assumption that only the real sector is subject to such shocks. We are interested in shocks that hit the real sector directly and compare the dynamic response of the economy with and without financial frictions in the financial sector. ${ }^{8}$ In the next section we will examine how the economy responds to shocks hitting the financial sector directly. Figure 3 shows

\footnotetext{
${ }^{8}$ In the context of our model, we can shut down financial frictions in the financial sector by either setting the monitoring $\operatorname{cost} \mu^{f}$ or the variance of idiosyncratic shocks $\omega^{f}$ to zero.
} 
the resulting dynamics as a percentage deviation from the deterministic steady state for a subset of variables.
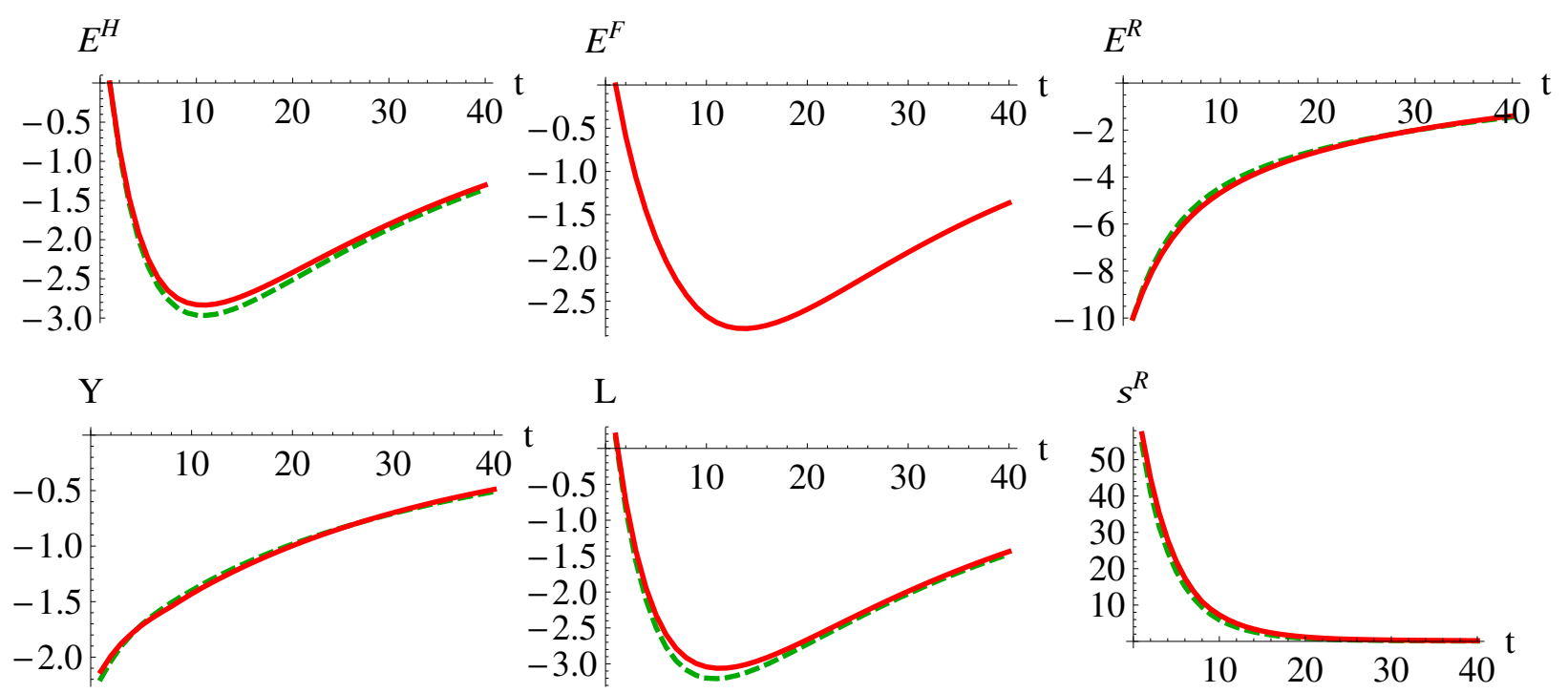

Figure 3. Shocks to real sector

Note: With (solid) and without (dashed) frictions in the financial sector (\% deviations from Steady State.)

In absence of financial frictions in the financial sector, the borrowing rate for real sector firms includes a wedge over the rate of return on deposits determined only by the real sector's risk of default and bankruptcy costs. When we introduce financial frictions also in the financial sector, this wedge increases because the lender's risk of default and bankruptcy costs are now also priced. This effectively raises the cost of borrowing for the real sector and consequently lowers its leverage and the capital stock in the economy. Therefore, the introduction of frictions in the financial sector involves a change in the steady state. However, Figure 3 reveals that the responses to shocks in the real sector are virtually unchanged, at least for the baseline calibration. ${ }^{9}$ This is essentially because the intermediation margin charged by the financial sector stays rather constant in response to disruptions in the real sector.

\section{B. Financial sector as shock generator}

In the previous section we have exclusively considered the role of the financial sector in amplifying shocks affecting the real sector. But the financial sector can itself be a source of shocks. More specifically, we now consider how the effects of a given reduction in aggregate net worth depend on the sector that is directly absorbing the losses. As discussed in the presentation of the model, we consider an exogenous reduction in total net worth of 4 percent and compare the impulse response functions of the model when this loss is allocated to the household, the financial, or the real sector. Figure 4 shows the resulting dynamics as a percentage deviation from the deterministic steady state of the model. The top row shows the evolution of net worth in each

\footnotetext{
${ }^{9}$ It is important to note however that our model does not incorporate endogenous asset prices, which in the financial accelerator literature is a key mechanism to generate quantitatively important amplification effects (Bernanke et al. (1999) and others).
} 
sector, the second row traces the responses in consumption, loans and output, and the third and fourth rows focus respectively on the financial and real sector by considering the risk-free borrowing rates, the borrowing spreads and the leverages. Each period of the simulation represents one quarter.

Consider first the responses when the net worth loss is concentrated on the real sector (dotted lines). These are similar to those considered in the previous section, but not identical since now the household's policy functions are solved taking into account the possibility of net worth shocks also on the household and financial sector. The fall in the capitalization of the real sector reduces invested capital and output and drives up the marginal return on investment. The real sector's leverage therefore increases leading to higher borrowing spreads. From the perspective of the household, the lower capitalization of the real sector implies lower future wages. In an effort to smooth consumption over time, the household immediately reduces consumption which keeps falling over time. This is because the household's net worth gradually shrinks due to lower wages and rates of return. The process of recovery is slow and characterized by a gradual de-leveraging of the real sector.

Let us now turn to the case in which the net worth shock is concentrated on the financial sector (solid line). Note that the capitalization of the financial sector suffers a percentage loss much larger than the one experienced by the real sector when the shock hits the latter. This is because financial sector's net worth is the smallest and leverage the highest, so that if an equal-size shock hits the financial sector it produces a much larger percentage reduction in capitalization. The capital loss leads to much higher leverage and borrowing spreads for the financial sector, whose ability to intermediate funds is severely impaired. The demand for deposit and supply for loans contract considerably leading to a strong reduction in the deposit risk-free rate and increase in the lending rate. Lower lending coupled with higher bankruptcies in the financial sector leads to a large contraction in GDP similar in magnitude to the 2008 US recession. 

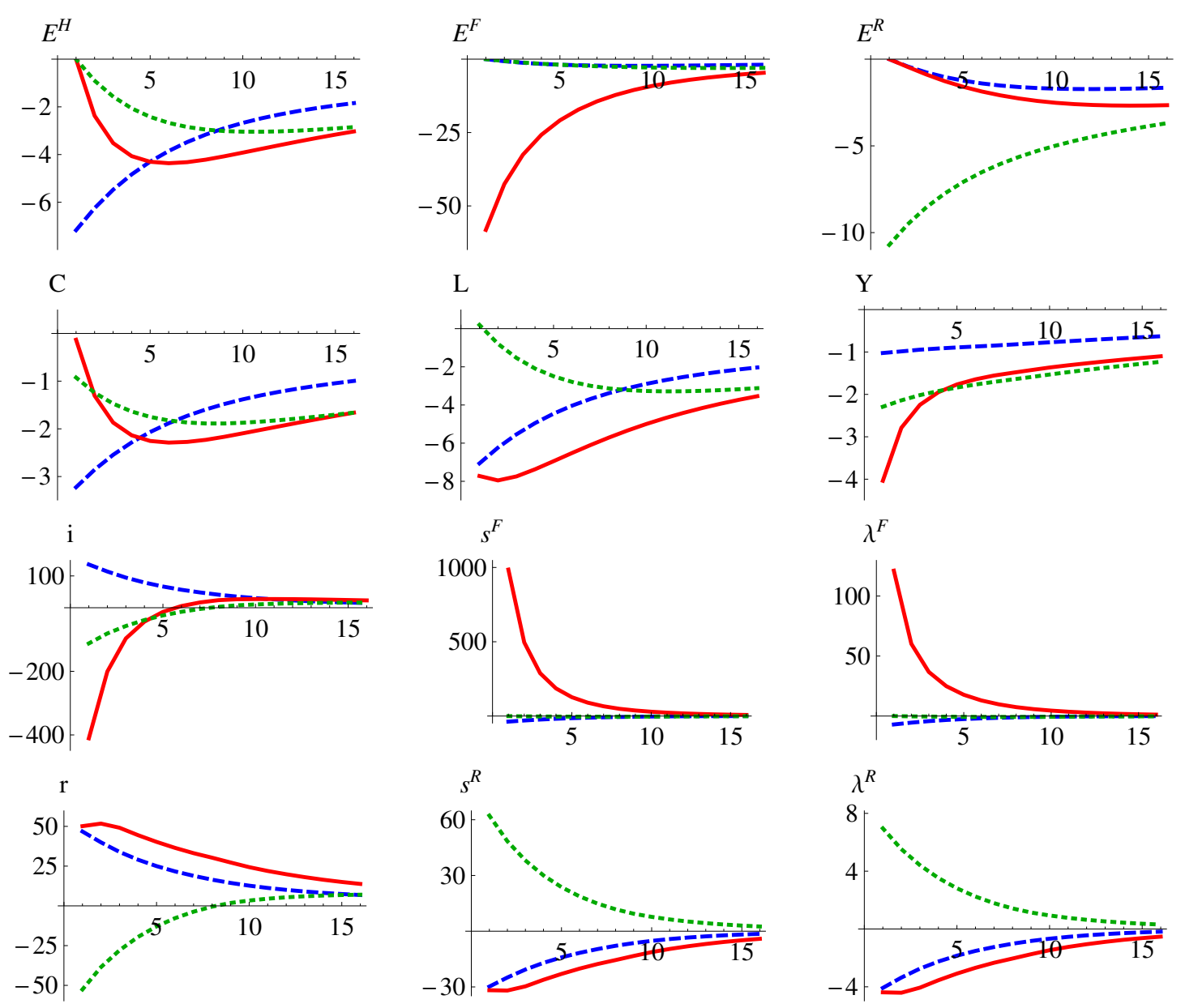

Figure 4. Impulse response functions from net worth shocks

Note: Shock to household (dashed), financial (solid), and real (dotted) sectors (\% deviations from the steady state)

Finally, we consider the model responses if the net worth loss falls on the household sector (dashed lines). Lower household wealth implies lower deposits, lower lending and ultimately lower output. The reduction in output is however very moderate compared to when the shocks are concentrated on the financial and real sectors. This largely depends on the behavior of the rate earned on deposits. Shocks to the financial and real sectors reduce the deposit rate and thus discourage household saving which is needed to speed up the recovery. This is due to the presence of financial frictions which lead to an increase in spreads after net worth losses. Conversely, when the shock is concentrated on the household sector, the deposit rate increases and the household responds by cutting consumption and supporting new investment.

Summing up, the model responses reveal that output losses are much more pronounced if a given net worth loss is concentrated on the highly leveraged financial sector. This observation provides the motivation for policies targeted to recapitalize the financial sector after a negative shock. 


\section{RECAPITALIZATION POLICIES}

How large are the potential welfare gains from recapitalizing the financial sector after a negative net worth shock? Can recapitalization funds be taken from the real sector or only from the household sector? How do gains vary with the size of the shock? We address these questions by comparing the household's welfare under different recapitalization policies. These recapitalizations may take different forms, including government equity injections, debt-to-equity conversion, asset swaps at above market rates, or simply overly lax monetary policy for a prolonged period of time. All of these interventions can ultimately be seen as wealth transfers across sectors, generally from savers to borrowers. In this section, we compare welfare when we implement these wealth transfers in response to shocks, without taking a stand on the particular form of implementation. Comparing in detail the effectiveness of alternative implementation options becomes worthwhile only after establishing that the potential welfare gains from recapitalizations are reasonably large.

Similarly, in our model the introduction of recapitalization policies does not generate moral hazard leading to further banks' risk taking. ${ }^{10}$ We believe that moral hazard is likely to be relatively small as long as recapitalizations are used exclusively in response to rare but large aggregate shocks. Managers and shareholders should indeed still be disciplined in their leverage decisions by the idiosyncratic shocks which remain uninsured. Furthermore, recapitalizations can be designed as to involve considerable losses for banks' managers and shareholders. In any case, analyzing the extent to which moral hazard can limit the benefits from recapitalization policies is not particularly interesting without first establishing that the potential gains from recapitalizations are substantial.

To assess welfare in the presence of recapitalization policies, we solve for the household's value function under the expectation that the financial sector will be fully recapitalized in case of a net worth shock. Recapitalization funds may come from the household sector, from the real, or from both. We express welfare gains as the permanent percentage increase that households would require to voluntary remain in a world without recapitalization. This is computed by solving for the $\nu$ such that:

$$
(1+\nu)^{1-\gamma} v^{h}\left(E^{h}, E^{f}, E^{r}\right)=\tilde{v}^{h}\left(\tilde{E}^{h}, \tilde{E}^{f}, \tilde{E}^{r}\right)
$$

where tilde denotes variables in the presence of recapitalization. Regarding where in the state space to compare welfare, we will consider two cases. First, we compute the welfare gains at the determinist steady state without recapitalization policies, defined at the point in the state space the model converges to if not disturbed by net worth shocks. These can be thought of as the gains from introducing recapitalization policies in an economy that has not had them so far. Second, we assess the welfare gains evaluating the value functions with and without recapitalizations at their own deterministic steady states. So we will compare welfare at the deterministic steady state for the model without recapitalization with welfare at the steady state in an economy with recapitalization policies. This captures the gains from having recapitalization policies.

\footnotetext{
${ }^{10}$ This is because the maximization problem solved by financial intermediaries is linear and aggregate shocks do not affect borrowing spreads since they are realized after the within-period debt is repaid.
} 
The welfare gains are plotted in Figure 5 as a function of the recapitalization share financed by the household sector. The dashed and solid lines refer respectively to the comparison at the non-recapitalization steady state and at each value function's steady state. Considering first the gains at the non-recapitalization steady state, we observe that if the financial sector is entirely recapitalized with funds from the household sector, the welfare gains are equivalent to a permanent increase in consumption of $0.12 \%$. To put this number into context, these gains are similar to those derived by Lucas (1987) from the elimination of the US business cycle. We do not want to enter the debate on whether these gains are small or large, but we simply want to highlight that recapitalization polices in response to large financial shocks are equally deserving of consideration as policies to reduce business cycle fluctuations. The model implies indeed that the potential gains from recapitalizing the financial sector in case of large but rare net worth shocks (occurring in our calibration only every 75 years) could lead to gains as large as those from completely removing business cycle fluctuations.

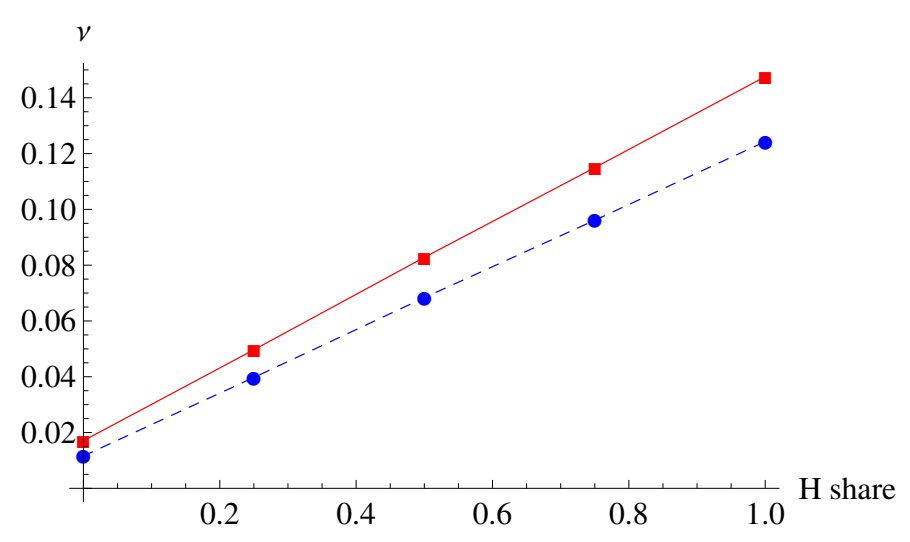

Figure 5. Welfare gains from recapitalization and sources

Note: From introducing (dashed) and having (solid) recapitalization policies as a share of the recapitalization financed by the household sector

Figure 5 also shows that the gains from recapitalization are decreasing if the household provides a lower share of the recapitalization funds which are thus taken from the real sector. Interestingly the gains from recapitalizing the financial sector remain positive even if the recapitalization is entirely financed by subtracting resources to the real sector. This may seem counterintuitive since the purpose of the recapitalization is ultimately to support investment by the real sector. The difference in leverage between the two sectors explains the result. The much higher leverage in the financial sector, particularly after a negative net worth shock, implies that funds moved from the real to the financial sector are able to support much larger lending and thus increase final investment. Furthermore, the recapitalization of the financial sector reduces bankruptcies which allow for a faster re-accumulation of aggregate capital.

Let us now turn to compare welfare at the steady states of economies with and without recapitalization policies (solid line, Figure 5). Welfare gains are now even somewhat larger, essentially because the presence of recapitalization policies moves the economy to a higher steady state level of net worth in all sectors. At a first glance, this may seem surprising since recapitalization policies should reduce the household's precautionary savings by removing the risk of wage reduction during financial crisis. This is indeed the case, but recapitalizations also 
eliminate the big decrease in the risk-free deposit rate associated with net worth shocks on financial intermediaries. ${ }^{11}$ As a consequence, the expected higher return on savings stimulates capital accumulation and leads the economy towards a higher welfare steady state. This is a second channel through which the adoption of recapitalization policies can improve welfare.

Finally, we consider how the welfare gains vary with the size of the net worth shock. Figure 6 traces the welfare gains from fully recapitalizing the financial sector with funds taken from the household sector. Gains are again presented by comparing welfare at the non-recapitalization steady state (dashed) and at each value function's steady state (solid). We observe that the gains are exponentially increasing in the size of the shock. This result is relevant to think about the merit of recapitalization policies if there are costs associated with transferring resources across sectors. We have so far neglected that implementing recapitalization policies can be costly, since they could create distortions and require the creation of public agencies to administer the recapitalization process. In so far as these costs involve a fixed component, recapitalization policies should thus be confined to respond only to large shocks. The exact quantification of this threshold is beyond the purpose of our analysis and would be contingent on the particular implementation mechanism for the recapitalization.

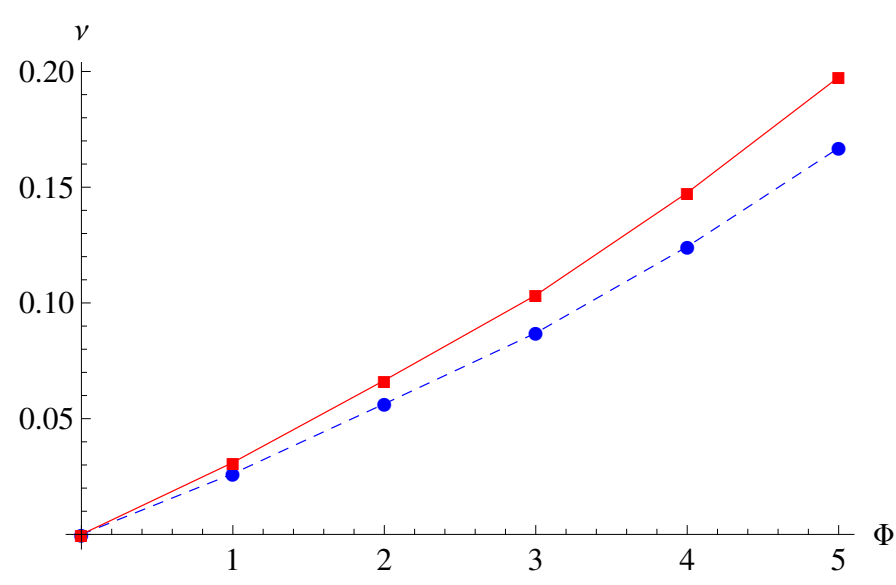

Figure 6. Welfare gains from recapitalization and size of the net worth shock Note: From introducing (dashed) and having (solid) recapitalization policies

\section{UNCERTAINTY SHOCKS}

Notice that in our model, idiosyncratic risk is a key ingredient in generating agency costs, since the latter arise from the interplay between the costly monitoring of projects and the risk of bankruptcy. We now turn to examine the dynamic responses in our model to changes in idiosyncratic risk in the financial sector. Recent literature has discussed the importance of uncertainty shocks similar to those we consider and argued that they contribute importantly to

\footnotetext{
${ }^{11}$ Note that the knowledge that shocks affecting the financial sector will be passed to the household through recapitalization policies reduces the expected rate of return on savings. However, this negative impact on expected returns is more than compensated from avoiding the negative real interest rates that would be associated with a financial crisis.
} 
business cycle fluctuations. Some examples include: Christiano et al. (2009), Bloom et al. (2011), Gilchrist et al. (2010), and Arellano et al. (2011).

Figure 7 depicts the dynamic responses of the model following a permanent increase (solid line) and decrease (dashed line) in idiosyncratic uncertainty in the financial sector equivalent to 20 percent of the baseline standard deviation. In absence of limited liability in the financial sector, the change in its idiosyncratic risk would be inconsequential given the linearity of the financial entrepreneur's problem. However, limited liability implies that variations in idiosyncratic risk lead to changes in default rates.

Consider for instance the case of a decrease in idiosyncratic risk, the lower risk of default implies that the spread on financial intermediaries' borrowing rates decreases. With lower borrowing costs, financial intermediaries find it profitable to increase leverage and lending. The latter effect increases the demand for deposits, which discourages consumption and stimulates household savings by pushing the risk-free rate up. Higher lending in turn pushes down the borrowing costs for firms in the real sector which lever up as well. Consequently, the capital stock and output rise. Note that net worth in the financial sector gradually decreases. This is because limited liability implies that changes in idiosyncratic risk affect only the upside returns. Therefore, lower idiosyncratic risk reduces profitability which leads to lower capitalization. In contrast, net worth in the real sector increases since profitability goes up thanks to the lower borrowing costs. All these effects carry through symmetrically when the shock is an increase in idiosyncratic uncertainty.

One interesting implication of this exercise is that a reduction in the idiosyncratic uncertainty increases leverage in the financial sector, which in turn increases its vulnerability to aggregate shocks. It is useful to draw a parallel between this exercise and what happened prior to the crisis that started in the U.S. in 2007. The reduction in idiosyncratic uncertainty in our model could be interpreted as the impact of financial innovation. For instance, the increasing use of credit default swaps and securitization that grew rapidly over the decade that preceded the crisis had precisely the effect of reducing idiosyncratic risk. Over this same period, we witnessed a significant increase in leverage, which in turn increased the economy's vulnerability to systemic risk, or aggregate shocks. The outcome of the simulation performed here is consistent with these stylized facts.

\section{A. Recapitalization Policies and Idiosyncratic Risk}

We now re-examine the welfare gains obtained earlier with the goal of studying how they vary with idiosyncratic risk. Notice that on the one hand, one would expect recapitalization of the financial sector to become less relevant as we approach zero idiosyncratic risk in the financial sector because at that point financial frictions in the sector become irrelevant. However, as shown in the previous section, lower idiosyncratic risk implies higher leverage which increases the vulnerability of the economy to aggregate shocks. The impact of changes in idiosyncratic risk on the welfare gains from recapitalization policies is thus ex-ante ambiguous.

To shed light on this issue, Figure 8 shows the welfare gains from recapitalizing the financial sector with funds from households under different levels of idiosyncratic risk in the financial 


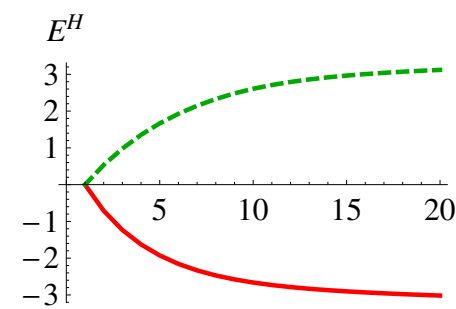

$\mathrm{C}$
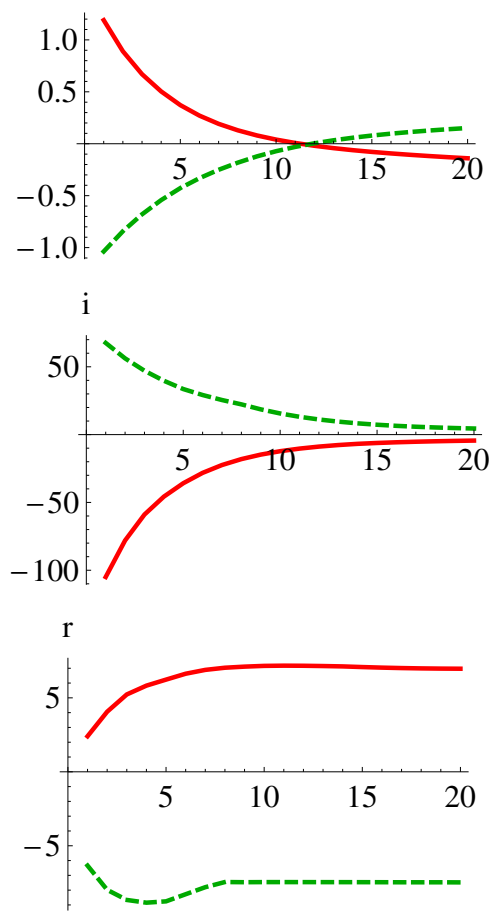
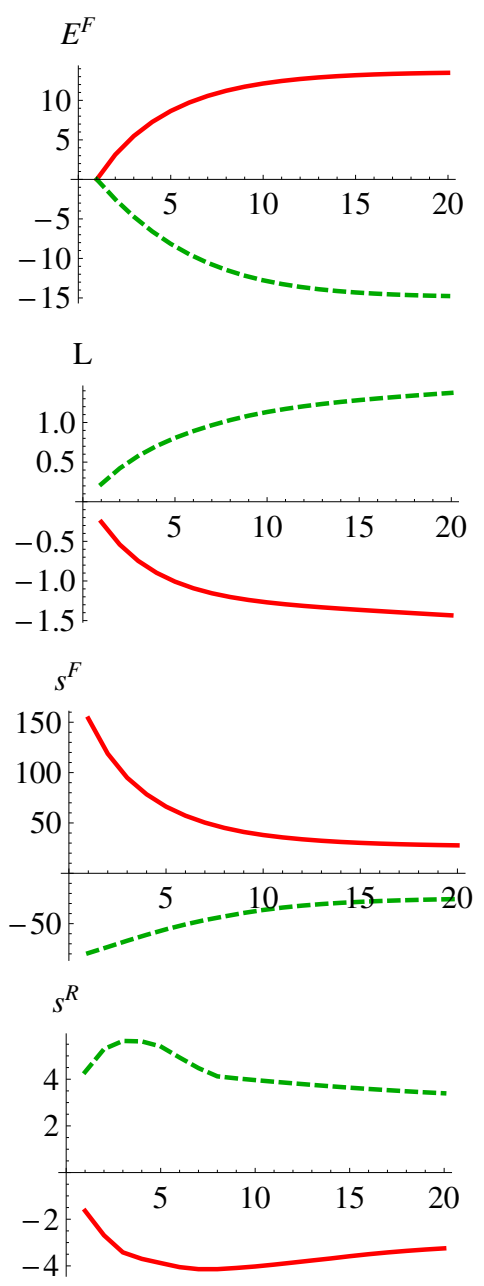
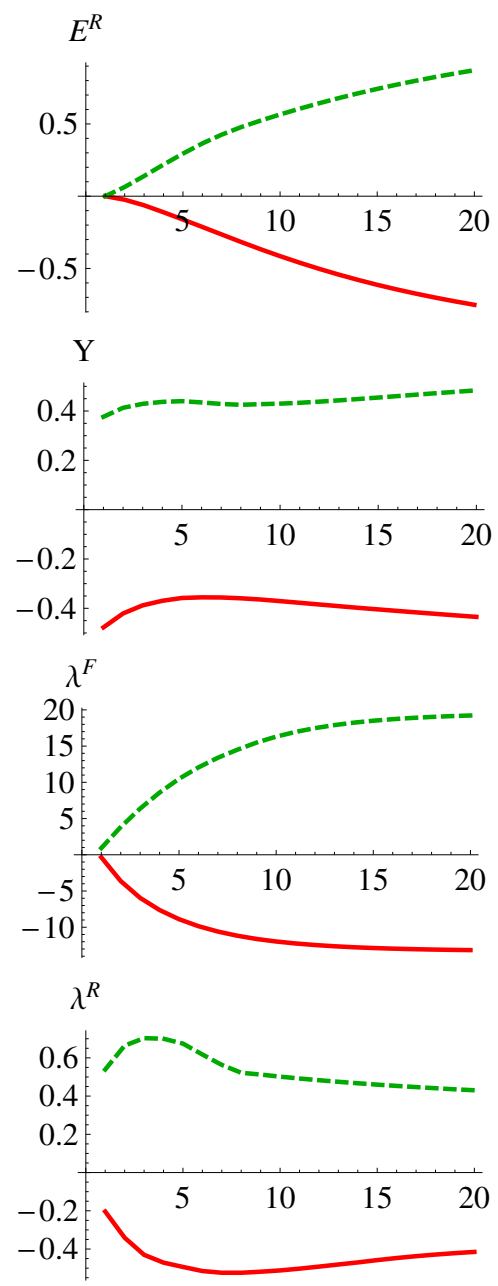

Figure 7. Impulse response functions from net worth shocks and idiosyncratic risk Note: $20 \%$ increase (solid) and decrease (dashed) in idiosyncratic risk in the financial sector (\% deviations from the steady state)

sector. Notice that as idiosyncratic risk decreases, the gains increase, which results from the increasing leverage in the financial sector that we described earlier. However, for further reductions in idiosyncratic risk, the gains start to decrease because financial frictions become less relevant enough to trump the increased leverage effect. Consequently, the model implies a non-monotonic relationship between the welfare gains from recapitalization and the financial sector's idiosyncratic risk. 


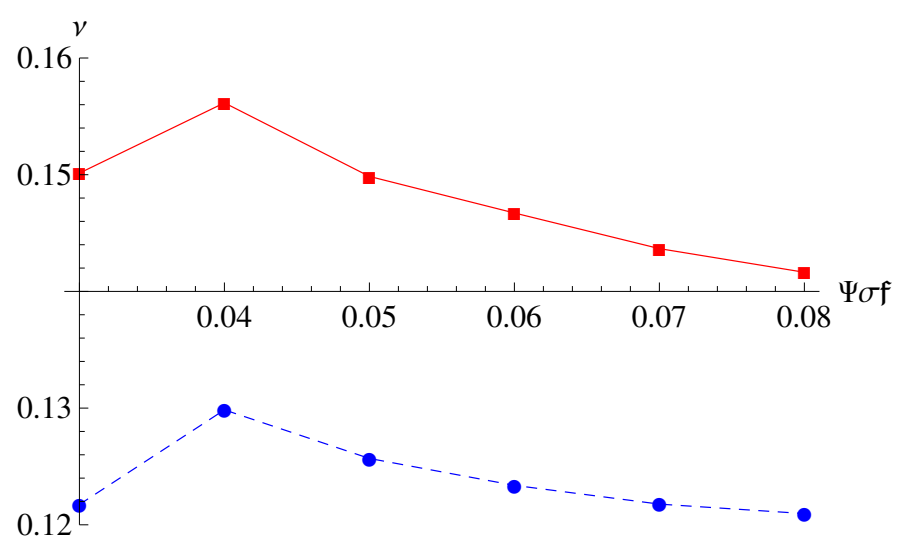

Figure 8. Welfare gains from recapitalization and idiosyncratic risk

Note: From introducing (dashed) and having (solid) recapitalization policies as a function of idiosyncratic risk in financial sector

\section{Conclusion}

The crisis that started in the U.S. in 2007 brought about a significant deterioration in the balance sheets of financial institutions followed by a sharp economic contraction. In response to these events, massive policy intervention was deployed to contain the real effects of the crisis, restore balance sheets, and speed up the recovery. These events have revamped significantly the interest of academic research in studying the role of the financial sector and the scope for policies to confront financial crises.

This paper contributes to the growing literature on financial crises by developing a dynamic-stochastic general equilibrium framework to assess the impact of large balance-sheet shocks and the merit of recapitalization policies. The key aspect of the model is the explicit modeling of financial frictions on both financial intermediaries and real firms. This allows us to study how the effects of a given net worth loss in the economy depend on which sector is primarily affected. Another distinctive feature is that we solve the model with global solution methods, instead of using linearization around the steady state. We can thus more confidently assess the quantitative impact of large shocks that involve dynamics substantially away from the steady state.

Calibrating the model with U.S. data, we show first that shocks that impair the balance sheets of the financial sector generate the largest contraction in output because of the high leverage in the sector. Responding to these shocks by recapitalizing the financial sector can lead to substantial welfare gains, roughly similar to those that would be obtained if business cycle fluctuations were entirely removed. The maximum welfare gains are obtained when the recapitalization is financed with funds from households, but using resources from the real sector also generates gains. The welfare gains are higher in response to larger losses in the financial sector and can possibly increase after a reduction in the financial sector's idiosyncratic risk which increases its leverage.

In this paper, we have framed the analysis of recapitalization policies in a very general way, by simply considering the impact of redistributing net worth across sectors. Having shown that this 
kind of redistribution can lead to considerable welfare gains, it becomes interesting to compare in future research the effectiveness of alternative implementation options. In this regard, it is also important to consider the implications for moral hazard, since recapitalization policies that do not penalize sufficiently banks' managers and shareholders can lead to excessive risk taking. Finally, the modeling framework developed in the paper can also be used to analyze the effects of macroprudential policies that aim to contain leverage across the various sectors of the economy. 


\section{REFERENCES}

Arellano, Christina, Yan Bai, and Patrick Kehoe, 2011, "Financial Markets and Fluctuations in Uncertainty," Unpublished Paper.

Bernanke, Ben, Mark Gertler, and Simon Gilchrist, 1999, "The Financial Accelerator in a Quantitative Business Cycle Framework," Handbook of Macroeconomics, Vol. 1, pp. 1341-1393.

Bloom, Nicholas, Max Floetotto, and Nir Jaimovich, 2011, "Really Uncertain Business Cycles," Unpublished Paper.

Carlstrom, Charles T., and Timothy S. Fuerst, 1997, "Agency Costs, Net Worth, and Business Fluctuations: A Computable General Equilibrium Analysis," The American Economic Review, Vol. 87, No. 5, pp. 893-910.

Carroll, Christopher D., 2006, “The Method of Endogenous Gridpoints for Solving Dynamic Stochastic Optimization Problems," Economics Letters, Vol. 91, No. 3, pp. 312-20.

Chen, Nan-Kuang, 2001, "Bank Net Worth, Asset Prices and Economic Activity," Journal of Monetary Economics, Vol. 48, pp. 415-436.

Christiano, Lawrence, Roberto Motto, and Massimo Rostagno, 2009, "Financial Factors in Economic Fluctuations," Working Paper.

Cúrdia, Vasco, and Michael Woodford, 2009, "Credit frictions and optimal monetary policy," BIS Working Papers 278, Bank for International Settlements, ).

Del Negro, Marco, Gauti Eggertsson, Nubuhiro Kiyotaki, and Andrea Ferrero, 2011, "The Great Escape? A Quantitative Evaluation of the Fed's Non-Standard Policies," Working Paper.

Gale, Douglas, and Martin Hellwig, 1985, "Incentive-Compatible Debt Contracts: The One-Period Problem," The Review of Economic Studies, Vol. 52, No. 4, pp. 647-663.

Gertler, Mark, and Nobuhiro Kiyotaki, 2009, "Financial Intermediation and Credit Policy in Business Cycle Analysis," Handbook of Monetary Economics, Vol. 3. and Peter Karadi, 2010, “A Model of Unconventional Monetary Policy,” Journal of Monetary Economics, Vol. 58, No. 1, pp. 17-34.

Gilchrist, Simon, Jae W. Sim, and Egon Zakrajšek, 2010, “Uncertainty, Financial Frictions, and Investment Dynamics," Working Paper.

Hirakata, Naohisa, Nao Sudo, and Kozo Ueda, 2011, "Capital Injection, Monetary Policy, and Financial Accelerators," IMES Discussion Paper No. 2011-E-10.

Holmstrom, Bengt, and Jean Tirole, 1997, "Financial Intermediation, Loanable Funds, and the Real Sector," Quarterly Journal of Economics, Vol. 112, No. 3, pp. 663-691.

Kiyotaki, Nobuhiro, and John Moore, 1997, “Credit Cycles,” Journal of Political Economy, Vol. 105, No. 2, pp. 211-248. 
Kollmann, Robert, Werner Roeger, and Jan in't Veld, 2012, "Fiscal Policy in a Financial Crisis: Standard Policy vs. Bank Rescue Measures," American Economic Review Papers and Proceedings (forthcoming).

Lucas, Robert E., Jr., 1987, Models of Business Cycles (Basil Blackwell, New York).

Meh, Césaire A., and Kevin Moran, 2010, "The Role of Bank Capital in the Propagation of Shocks," Journal of Economic Dynamics \& Control, Vol. 34, pp. 555-576.

Quadrini, Vincenzo, and Urban Jermann, 2011, "Macroeconomic Effects of Financial Shocks," American Economic Review. Forthcoming.

Townsend, Robert M., 1979, "Optimal Contracts and Competitive Markets with Costly State Verification," Journal of Economic Theory, Vol. 21, No. 2, pp. 265-935.

Williamson, Stephen, 1987, "Costly Monitoring, Loan Contracts, and Equilibrium Credit Rationing," The Quarterly Journal of Economics, Vol. 102, No. 1, pp. 135-145. 